Received: Novembre 05, 2014. Accepted: February 02, 2015

\title{
Historiosophy of August Cieszkowski in the context of contemporary consciousness
}

\section{DANIEL ROLAND SOBOTA}

University of Technology and Life Sciences in Bydgoszcz bobota@wp.pl

\begin{abstract}
Cieszkowski's philosophy embodies the most influential trends in philosophy and culture of the nineteenth century. This does not mean, however, that Cieszkowski's philosophy has today only historical character and it is good topic for some historians of philosophy. On the contrary. Although Cieszkowski used Post-Hegelian language and concepts, at the core his philosophy is an experience which has got a fundamental complexion. It is an experience of the dialectic of history. It underlies not only the history of philosophy of the nineteenth century, but also lies at the root of modern consciousness, as determined by hermeneutics and postmodernism. The ancestor of the transversal reason is a cunning reason of history. Postmodernism, which focuses on pluralism and diversity, is closely related to the era of the "end of history" and post-history. The last term, just as the "post-modernism" is a historiosophical concept. The present of Cieszkowski's philosophy of history allows us better understanding the philosophical foundation of contemporary culture.
\end{abstract}

Keywords: Post-Hegelian thought; philosophy of history; Postmodernism. 
It is a privilege of theology and philosophy to pose the questions for which one cannot find empirical answers. That is the nature of such questions, which relate to things fundamental and ultimate: they maintain their significance because no answers makes them be silent. There wouldn't be questions about the meaning of history if that sense were manifested in the historical events themselves. On the other hand, history may seem meaningless only with respect to some ultimate sense. Disappointments occur only where there are expectations. The very fact that we make enquiries about the entire history with regard to sense and non-sense is itself historically conditioned: that uncurbed indagation was given rise to by Judeo-Christian mindset. The serious enquiries about the ultimate meaning of history transcends all the possibilities of knowledge and takes our breath away: transports us into the vacuum, which can be filled only with faith and hope.

Löwith 2002, 7-8

The heritage of August Cieszkowski reminds us of the lens focused on the most influential philosophical and cultural movements of XIX century. His "philosophy of action", which consists of his philosophical and social writings as well as his lavish political, social and economic involvement is - the "sum of an epoch" or - putting it in a different manner, following Hegel - "self-consciousness of an epoch"- in which his philosophy happened to emerge and evolve. The exceptional times and the place in which that philosophy was called into being determine its strict belonging of ideological and historical nature. Cieszkowski was clearly aware of it: "Our times are grandiose and sublime. Each day I thank God that I was born in those days" (Cieszkowski 1972, 299). Because Cieszkowski's thought reflects the entirety of the spiritual efforts of that epoch, it is impervious to being classified as only one of its aspects. There are well-known problems concerning ordering Cieszkowski's philosophy in terms of the then philosophical tendencies (Walicki 1972; Jakubowski 1989). The richness of his philosophy is testified by both the extent of its inspirations - it is not only German and French philosophical tradition that inspired it but also the heritage of Polish romanticism - and the range of influence it managed to exert. Having pre- 
served in itself the seminal plots of philosophy as it was in the first half of XIX century, it managed to creatively transform them by anticipating the philosophical issues of the latter half of XIX century. And as it was born in XIX century deriving its vital forces for its own development and so it died with the dawn of XIX century itself. Despite the Polish publications of the major works by Cieszkowski in the first decades of XX century, his thought was unable to compete with the new philosophy of Lvov-Warsaw school and neither could it compete with phenomenology. The absence of Cieszkowski's philosophy in the thought of the previous century was not due to its lack of competitiveness but rather to its fervent historiosophical optimism, which was a disgrace when faced with the tragic events of the previous century. Even if we live in the times of fulfillment, it is definitely not the epoch of the Holy Spirit and even less the Kingdom of Heaven on Earth, while it is at best - according to Nietzsche's prophecy and which was confirmed by (among others) Heidegger and Vattimo - the epoch of realized nihilism.

What is then what we except from the thought of August Cieszkowski, reminiscing over his philosophy on the occasion of his 200 birthday anniversary? Is it merely because of its strong affinity to the entirety of XIX-century culture, that we owe his philosophy the credit of remembrance exclusively due to some commemorative reasons and/or the reasons related to the interest in the history of philosophy as such (or else Polish philosophy)? Or, colloquially speaking: Cieszkowski's philosophy is still valid!? Frankly speaking, my first contact with his philosophy terminated in its spontaneous dismissal. That's why, instead of posing the questions concerning its validity, which questions necessarily subordinate the value of the past events to the current needs; I decided to ask the inverted question. Namely, instead of measuring the value of the work with our standards, I posed the question whether we - contemporary people - are "contemporary" enough to hear the calling of the future and accept the challenge of the past - in that case the past is identified with the thought by Cieszkowski. Are we ready to argue with the thinker from Wierzenica?

Does my inverted question contain anything more than indagating about what is universal about Cieszkowski's works? Obviously one can 
- and it is even advisable - take up and even take further such a type of attitude to the works of the past. With reference to Cieszkowski's thought, it can be put in the following manner: though XIX century irrevocably stigmatized his philosophy, it cannot be measured solely by his position.

His philosophy seems to be not far from exemplifying the historical law of masterpiece: elevating what is local to the status of the universal. And that is not about its claims for being absolute but about its factual layer. Addressing that universality and emphasizing what is "contemporary" in the eyes of Cieszkowski are certainly two different things. The latter is manifested when one exposes those threads in Cieszkowski's thought which proved vital for philosophy and culture in XX and XXI century. These encompass, among others, the conviction that what we face is the end of philosophy (post-philosophism) and the belief the times are ripe for actions and that is the actions that are of social nature. Or the belief that humankind can consolidate under the idea of ecumenism and economy based on commonly shared values (Walicki 2005, 132-133). Eventually, it might be shown that Cieszkowski's thought bears some resemblance to such influential philosophical proposals of XIX and XX century as the philosophy of Marx, Nietzsche or existentialism. Instead, let us try to take heed of something else; namely, the socalled "fundamental experience" - which concept laid the foundations for the cultural climate of XIX century and most of all for the philosophical works by Cieszkowski and which gave rise to experience determining the status of the contemporary man. This choice of the subject results from the deliberate and free decision of the author of the text; however, it does not mean that the choice is unmotivated. On the contrary, the choice stems from the post-Heideggerian hermeneutic and postmodern consciousness (which both delineate the contemporary mindset), in the centre of which there lies the concept of experience and that which is problematic. Before we embark on the deeper justification of that choice - the justification for which we will have to wait until we are fully aware of the decision we had made - let us recall the statement by Wodziński for advisory reasons: 
The history of "spiritual Europe" is the history of successive metaphysical epochs. The internal structure of each metaphysical epoch has a two-layer nature: characteristic historical experience and the ways of problematizing and articulating that experience. Each metaphysical epoch has its own characteristic fundamental problem then: the question of questions (it may be a blend of interrelated questions), which emphasizes its spirit and determines its singularity. The metaphysical auto-construction of the epoch inevitably demands being faced with the fundamental problem of the epoch. Without that act, a metaphysical epoch lacks identity, the epoch cannot see its own reflection in any mirror. Its image remains blurred and amorphous (Wodziński 1994, 603-604).

We claim that in the case of Cieszkowski's thought, that fundamental or mystical experience - because "mysticism is undeniably indispensable for philosophy", and mysticism is a "speculation in nuce"(Cieszkowski 1972, 152 ) - is the experience of dialectics of history. It was expressed in the fullest form in the XIX-century philosophy of history (Geschichtsphilosophie). ${ }^{1}$ That suggestion must give rise to some misgivings. Trying to oppose it, one might say that among Cieszkowski's beliefs his philosophy of history seems to be the thought that is the least appealing when perceived from today's perspective. That is because it seems that "we are on the verge of the modern historical thinking” (Löwith 2002, 6). After the release of Prolegomena zur Historiosophie (1838), that sort of - historiosophical - attitude to history had to defend itself against not at all unreasonable - as it transpired to be so having considered the upcoming aversion to whatever philosophy of history - objections to "making them metaphysical" and hence - to their falsification. The objections were pronounced by the adherents of clearly anti-metaphysical, that is a scientific, attitude to history. Its most outstanding representative was the so-called German historical school. Even if we assume that the objections to the philosophy of history may be justified

1 In the present paper, we use the same definitione of the term „philosophy of history” as used by K. Löwith: "the term "philosophy of history « means the systematic explanation of general history in the light of the principle, due to which historical events and successions are interconnected and they refer to some ultimate sense" (Löwith 2002, 5). 
and may confirm that it is philosophically unsound; we may, first of all, at the same time agree with those thinkers who can see the traits typical of the philosophy of history in the attitude to history as adhered to by the German historical school (Gadamer 1993, 199-216; Schnädelbach 1992, 72-85). Second of all, we might note that, follow G. Vattimo, but for the philosophy of history, running counter to the data-gathering-kind-of historical thinking (the philosophy of history for early Nietzsche was a remedy against historical thinking threating life itself - just to successively become superseded by Nietzsche himself with his "philosophy of daybreak"), there wouldn't have been any possibility of establishing hermeneutic and postmodern philosophy, which after all shaped the philosophical consciousness of the second half of XX century (Vattimo 2006, chapter X). Thirdly, we believe that the latter are the movements of strictly historiosophical nature. Thus, we assume the position that the questions posed by XIX-century philosophy of history and the experience of dialectics of history that lay its foundations have an invaluable inherent heuristic power. That power can be - and even must be - taken up and developed to appreciate the current philosophico-historical situation. To endorse the assumed strategy of the present paper, the strategy juxtaposing post-Hegelian philosophy of history and contemporary intellectual movements, let us recall the words by the leading representatives of hermeneutics and postmodernism. Hans-Georg Gadamer says:” The dispute with Hegel has the central significance for the problem of hermeneutics" (Gadamer 1993, 323; idem 2006, 254). Wolfgang Welsch adheres to the above statement: "One can treat postmodernism as a consequence and the climax of post-Hegelian line of development" (Welsch 1998, 239).

As far as this suggestion of treating Cieszkowski's philosophy of history as a serious inspiration for contemporary thought goes, one must note that a hypothesis of this type relates both to the form and to the content of what we call "inspiration". As far as the form goes, we do not treat the inspiration as a conscious borrowing or influence; however, referring back to its Latin etymon (inspirare) and the Western theological tradition, we just want to underline that it is all about some dialogical, spiritual 
(spiritalis) community (communio) between the old and the new (Ratzinger 1998, 324-327). ${ }^{2}$ Spirit, as it is widely known, is a basic figure in the philosophy of history of XIX century. Spirit is history. His/its characteristic mode of being is a circular move of transcendence and mediation, the basis of which is formed by a certain internal distinction between not-being-itself or being-outside-itself. Hence, talking about the community of spirit has some dialectical and self-contradictory element because the spiritual community means the internal agony (the fight of a spirit with itself), which does not terminate in the demolition of the adversary but it does in maintaining and respecting it. That spiritual fight of the new against the old makes it hard to state any simple identity or the unambiguous distinctive sing of a given epoch and its most exquisite output. That is why it is right to say that although each epoch has its own sense and characteristics, the epochs, considering their geneses, still bear the traces they wanted to shake off. As Cieszkowski said: "any novelty is an act of remaking” (Cieszkowski 1972, 26). Exposing that spiritual sense of the concept of inspiration is to prevent thinking about inspiration as a conscious take-over. From that formal understanding of inspiration as the history of spirit, there follow definite entailments related to its content. On the one hand, it is certainly not easy to admit that historical consciousness, which elevated the history to the rank of a philosophical problem, has these days the same force determining the understanding itself and the world by the contemporary man as it did one hundred years ago. On the other hand, it is hard not to admit that although suspended, history remains still alive in a sense; namely, it serves as "the preparation and the premise" of the dominating awareness of pluralism and cultural relativism. It is present in the discourse over "the crisis of culture", "the end of history" as well as "civilization war". There would be no culture of the second half of XX century - shaped on the one hand by hermeneutic consciousness and on the other by postmodernism - if there were no XIX-century historical consciousness and historism resulting from it (Schnädelbach 1992, 63-72). Whereas

2 According to Augustine, Spirit in Trinity is the dialogical communion and oneness between Father and Son. Spirit is love and gift. 
the latter, by situating the nations along the axis of time, demonstrated pluralism and the relativity of each artifact from the perspective being the integral moment of the entirety of "history", which is incidentally what hermeneutic philosophy refers to; the postmodern vision of reality, confronting the variety of currently existing cultures, demonstrates "the same" from the available perspective of the global space, which one can avail of thanks to the latest technological inventions. The predecessor of transversal mind is the cunning spirit of history itself. That "immobility" of postmodern experience is often expressed with the help of oxymoron, that is as "the end of history" or briefly as "post-history" (Vattimo 2006, $6-7,11) .{ }^{3}$ The latter term, quite like postmodernism itself is a historiosophical concept.

But the transition from the historical consciousness of XIX century to the mindset of the latter half of XX century, from the experience specified by general history to the experience controlled by the category of the global space was not implemented directly and smoothly; instead, it was like a leap over the abyss, the abyss being the events of the first half of the previous century. The road from XIX-century philosophy of history to philosophy of the turn of XX and XXI century was beaten through "transitional reasoning", "thinking in transition" - as it was put by Heidegger (Heidegger 1996, 13). Trying to grasp the hidden (non)sense of that thinking, which leads up to transcending any reflection operating on the ontological plane of distinction between Being-being and the axiological plane with the distinction now being good-evil, Cezary Wodziński christened it as "epiphany of evil". "The way of existence of the man in the contemporary epoch is the way of existing of the participant and the witness of the materializing (being manifested) evil" (Wodziński 1994, 605). As far as that awareness of evil is concerned, one must state that in the

\footnotetext{
Wolfgang Welsch rightly observes that the concept by Arnold Gehlen of "post-history" semantically overlaps with the term "postmodernism". In spite of that fact, according to our belief, that concept - bereft of any decadent semantic colourings - rightly connotes one of the aspects of postmodernism, which is flattening of that which before loomed far away from historical process to the current "now". For the distinction between postmodernism and post-historism see also: Welsch 1998, 26-27.
} 
context of the question about the need for the philosophical search for the meaning of history, that awareness is not only a symptomatic awareness of our times, but it is also and primarily the general premise of any philosophical reflection on history as such. Cieszkowski's philosophy of history also stems from the awareness of the great crisis ("what is happening in the world, the old world is dying, and the new is just getting born”), which not only incites the thought to ponder over history but also it calls the history itself into being. History is an incessant process of overpowering evil (Jakubowski 1989, 46, 53). Evil is a state of the tension inside the dialectical opposition. The opposites emerge as an answer to the question-solution (krisis). The fact that the reflection over history is connected with the experience of evil was very well explained by Nietzsche himself. Nietzsche observed that whereas happiness is related to the state of being hic et nunc, memory and reflecting back on the past takes shape when suffering (Nietzsche 1906, 57-59)4. Trying to understand suffering and evil, trying to impute some meaning to it and thus justify it somehow - that is because any explanation in search for reasons is the justification itself - the man weaves a story, the ultimate chapter (eschaton) which is being released from suffering, which brings consolation, and hence the termination of history itself. That is all connected with religion and faith in the power of redemption of God's Providence. Even if in the early modern philosophy of history, one relinquishes any reference to religious contexts, there is still a lively belief as for the redemptive termination of history. It was only philosophy of history (embarked upon on the turn of XIX and XX century) which remains exceptional in this respect: it looks ahead to the future and it can only see the growing deterioration and the decadence. At the basis of that pessimism related to the evaluation of the forthcoming future, amounting to the mood of fin de siècle, there lies the loss of faith in the ordering power of God and the liberating message of religion. Speaking more broadly: the experience of the influence of what was called nihilism in XIX century. What that act of looking ahead to the future (which is

4 The fact that learning and hence experience occurs while suffering has been known since

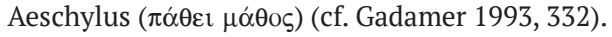


a Christian act by nature) was deprived of its theological and metaphysical roots (Gott ist tot), the sense of the future itself changed. The future which does not guarantee the hope for executing our plans makes the decision void of plainness and leads to quietism. Hence, we witness, so frequently in the thought of the turn of XIX and XX century, de facto curious calling for making decisions "in the name of death" in the times of fulfilled nihilism. In this manner, the earlier metaphysico-theological courage (naivety?) of perceiving and finding in everything the Oneness, which was related not so much to the need of abolishing all the differences, but more to the necessity of exposing them - that is because the difference is sharply visible only within Oneness - it transforms into the awareness of resignation and indifferent manifesto of "anything goes". This post-metaphysical state of being situated beyond differences but also beyond Oneness is called by Wodziński epiphany of evil.

Cieszkowski's thought - more than the ideas of German idealism, which commenced XIX century, more than revolutionary ideas of early Hegelians, who running counter to academic philosophy filled their life with risk; but even more than neo-Kantian philosophy, which dreaming about the coherent system terminated XIX century in the trenches of the World War I - shows, sometimes purely negatively what were the premises allowing for the above-stated transitions from the historical consciousness of XIX century through the early awareness of crisis - exemplified by war times and post-war times XX; up to the consciousness of the present century. In this vein, we will try to look once more at the chosen threads in Cieszkowski's philosophy of history commencing our journey from that philosophy itself, bridging the gap through to the contemporary philosophical standpoints concentrated around the idea of pluralism. Making use of the dialectical scheme of history, it might be formulated in that manner that XIX-century historiosophy by Cieszkowski exposing the differences within Oneness and Oneness within differences is a thesis. Philosophy of the first half of XX century, being located in its reasoning beyond differences is an antithesis. The thought of the latter half of XX century and the turn of XX and XXI century amounts to synthesis. What does this 
synthesis involve? We are about to take a closer look after stating our premises of that dialectical syllogism, focusing mainly on the thought by A. Cieszkowski.

\section{August Cieszkowski's philosophy of history}

In the letter dating back to June, 1836 addressed at his teacher, friend, publisher and a propagator of Hegels's thought, that is Karl Ludwig Michelet, young Cieszkowski writes that his main interest is "the philosophy of spirit" and that he is intending to write the work called Dialectics of History, in which he "will be forced to fight Hegel" because the latter in his logic did discover "the timeless law of dialectics" and established "the type of philosophical deduction"; yet, he was far from applying his discovery to the philosophy of nature, "and even less to the philosophy of spirit" (Cieszkowski 1972, 325-329). A few months later Cieszkowski resigns from this title since it is misleading in his opinion:

The reason for this misunderstanding lies in the confusion in the application of the concept dialectical, which can have many meanings. For example, there is purely negative dialectics, that is the second order of logical process. There is subjective dialectics of Eleatics and finally there is this dialectics which I meant - true objective dialectics, the internal process from which the unity of opposites develops, the normal movement of an object in its organic genesis; the development of an idea is perceived as one whole (Cieszkowski 1972, 333).

The task of detecting dialectics in the history will be called by Cieszkowski "the fundamental experience" (Cieszkowski 1922, 120) ${ }^{5}$. He concedes that Hegel did discover the idea of dialectics and he found in the history itself;

5 The first outline of Lord's Prayer before the German issue of Prolegomena in 1838. The direct inspiration for taking up the studies on his opus magnum - as he admitted himself during the conversation with his son - was the descension of the Holy Spirit upon him. It occurred while he was saying Lord's Prayer, conducted together with his father Paweł (Paul) giving thanks to the thoughts expressed in the Polish manuscript of Prolegomena (cf. Cieszkowski 1908, I-II). 
however, he conceived of history in the limited sense; that is as the past and the present and not at the same time he did not perceive history in the organic sense, that is identifying history with the past, the present and the future. Thus, as he did not search for dialectics a priori but he discovered it a posteriori in the history, he could not exhaustively describe all the potential inherent in history. It means that aprioristic construal of history is possible only by dint of considering that absolute a priori dimension, which is the future. Cieszkowski does not adhere to the idea of stopping history but that is not because he understands dialectics as the infinite negation but as the synthesis giving rise to the real oneness. The relation between dialectics of history and of the future - as conceived of by Cieszkowski looks different to the standpoint assumed by young Hegelian adherents, who in turn noticed the dimension of the future but did so purely negatively - as a permanent revolution. As far as Hegel ("the hero of history") is concerned, in his thought dialectics operates in the trenches of the past and that is why, being confined to the realm of what is gone, it cannot exhaust its (positive) potential. Hegel's dialectics was tailored for the needs of the phenomenology of the spirit and the science of logic; yet, when applied to history as such is afflicted with many shortcomings, excluding even the mentioned negligence of the fundamental significance, that is the absence of the aspect of the future. According to Hegel, history is terminated with the moment of the emergence of Hegel and Prussian country. It must be conceded that the history rolls on but without the complementation of what is gone with any additional sense. In Hegel's philosophy, reason and reality, thought and being are reconciled: what is rational is real, what is real is rational (Hegel 1969,17). It is all well-known how that famous thesis proceeded. "Hegelian rightists emphasized the fact it is only what is real is rational, while the leftists Hegelian stressed that it is only what is rational is also real" (Löwith 2001, 93). Cieszkowski's thought is closer to the latter interpretation: "Because reason has now come as far as to overcome its internal contradictions, the identical victory must take place in reality" (Cieszkowski 1972, 98). The conviction, shared with young Hegelian adherents, that being and thought are still at variance with each other is identical with 
the said fundamental experience of dialectics as well as with the sentiment that the history still has the open-ended character and that is why it allows for cherishing hopes for the future. Due to the fact that dialectics, contradictions, history, open-endedness, the future and hope are treated jointly - Cieszkowski, unlike young Hegelian adherents, make that fundamental experience of history won over by the experience of faith. That is because Christian faith is the experience of time in the modus of the future. That is why Hegelian end of history becomes in Cieszkowski's thought not as much the end of the world as the end of philosophy (Hegel's one). In other words: that assertion can be expressed in the form of an aphorism and so we might say that in Cieszkowski's opinion philosophy ends where the future begins. That holds true as far as we regard the future as an epoch of the history. On the other hand, that would be a false statement when we realize that any past exists only as some realized future, which means that any period of the past is some future which had lapsed. According to Cieszkowski, Hegel's decision to hold back and concentrate on the present stemmed from the fact that Hegel acted too passively, that is non-dialectically. The above-mentioned fundamental experience of dialectics of history did allow Hegel to introduce the so-far unknown dynamics into the realm of reasoning; yet, when it comes to nature and action Hegel was overly careful. Namely, he conceived of the events as they manifested themselves, whereas "the logos of history" is to be searched for actively. We are looking for "the systematic search for logic in history; whereas we can ascribe to Hegel only the speculative findings of history" (Cieszkowski 1972, 36). For Cieszkowski, investigating history is of the nature of searching. It results from the said experience of dialectics. The act of finding refers back to the past; searching is oriented towards the future. In accordance with this active-searching attitude towards history, Cieszkowski embarks on revising Hegel's philosophy of history by posing three questions. Asking about the history is not the same as studying it and persisting in existence in it. A question as such is a special form of epistemological and existential activity. Cieszkowski completes his list of historiosophical questions according to the manner, content and purpose: 
1. How? That is what is history and how it proceeds?

2. What? That is what content appears in each of the period of historical evolution?

3. Why? That is for what purpose the history goes on (the question of teleology)?

The answer to the first takes place in the realm of the construction, the second - deduction (realization), the third - extroduction (Cieszkowski 1972, 32, 53, 334). These questions, which was talked about by Wodziński in the excerpt quoted, form a blend of questions of mutually related questions and they amount to the complex expression of metaphysical fundamental experience, which shaped the spiritual climate of XIX century.

The fact that the answer to the first question is called „construction” by Cieszkowski does not mean that the results of "petty speculation” or any arbitrary conceptual schemes are not admissible. The attempt to answer the first question stems from the persistent holding on to the fundamental experience, which is dialectics of history and it leads to the vital correction of Hegel's vision of history. ${ }^{6}$ It does not occur at once obviously and it is not a revolutionary correction. The concept of "real objective dialectics of life" (Cieszkowski 1972, 98) certainly refers to the well-known Hegel's thought that any development of reason and being is performed as a transition from thesis through antithesis to synthesis. That transition means at the same time cancellation as well as preservation of what is cancelled (Aufhebung). Each of the constituents of that "great syllogism of the spirit of the world" (Cieszkowski 1972,16) is what it is only being assisted by the other constituents, which means that none of them has any substantial character but it has only the functional one. They are like the left and the right hand, like top and bottom, like question and answer. It is true that in the word 'absolutum', there resonates the unconditionality and unqualifiedness; yet, for Cieszkowski, the Absolute is "omni-conditionality and omni-qualifiedness"

6 That starting point - related to dialectics - and the „universal reference point” of Cieszkowski's thought, which reference point, despite its proximity, distinguishes itself both from Hegel himself as well as from neo-Hegelians - that starting point was emphasized by M.N. Jakubowski and M. Kozłowski (cf. Jakubowski 1989, 11-17; Kozłowski, 1996, 105). 
(Cieszkowski 1922, 108). The author of Prolegomena..., more strongly than Hegel, accentuated the internal contradictions occurring in each of the constituents of the antithesis. Each contradiction, including the contradiction between the thought and being, ensures the internal dynamics to history. Life is a tension between contradictions, a spiral movement divided into twists (Cieszkowski 1922, 106-107, 117).

Any progress, any life is and must be a series of fights, and if anybody denies those fights would deny the life itself. Any fight is indeed a dualism, is a friction, teasing, producing a tension where mutually opposite elements overcome each other. Fight is indeed a purpose, the accident and the destiny of a fight is a lively peace. The most faithful portrayal of such a peace is represented by a healthy Organism (Cieszkowski 1922, 139).

The concept of organism is "the physical category of general history”. Apart from physical categories, which encompass for instance the categories of mechanics and chemistry, "symbolically-typical categories" of light, magnetism, electricity and finally "real categories”, which has the natural influence on history and constitute its physical foundations, Cieszkowski enumerates first and foremost logical categories and then spiritual ones (Cieszkowski 1972, 31-47). Their deduction takes place while answering the second (what?) of the above-stated questions related to the philosophy of history. Comparing history with organism, which simultaneously symbolizes one of the moments in history - namely, the forthcoming future as a stage of the fulfillment of time and the performance the destiny of history, as an Epoch in which all the so-far contradictions will be reconciled - as well as all the history; so the very comparison was quite popular on the one hand in German philosophy of romanticism, which treated the opposition of spirit and nature as a superficial distinction, on the other hand - in the emerging sociological thought, which regarded social life in organic and evolutionary terms. ${ }^{7}$ Perhaps then that mode of functioning

7 It is worth mentioning that in the year of issuing Prolegomena, August Comte first used the term "sociology". Among many different analogies (and the same number of discrepancies) between Cieszkowski's thought and sociology of the latter half of XIX century, the 
of objective spirit justified and endorsed the use of the organism metaphor. As Cieszkowski pointed out, that which comprises "the grander of our time" is "striving for the real and harmonized organization"; "our times is the period of emergence, and the approaching of organization" (Cieszkowski 1972, 299). What encourages to draw a comparison between history and organism is incidentally the very category of life, which can be successfully applied to describe human existence (as in the later philosophy of life) and to the existence of a living organism (as in biology). In accordance with that organistic vision of history, Cieszkowski compares it - as Johann Gottfried Herder used to do before - also with the seed or the tree. The comparison between history and a living being entails that because "the cessation of an internal fight within the organism is death", the internal fight in history will never cease to exist; even when that organism of history will reach its destination. Reconciling dialectical contradictions does not involve the cessation of any movement and the evaporation of any tension but it involves their harmonized adjustment. The fight cannot be annulled but introduced. It relates to "harmonized fight”. „Harmony without the fight is an abstraction” (Cieszkowski 1923b, 119-122).

The application of dialectical syllogism and the physical category of organism to the philosophy of history leads to a significant rectification of Hegelian philosophy of history. What comes to the fore is the issues related to periodization (Pot 1999, 1. main part, 3. part; Sobota 2010, 731-764). Every division of history into periods must be based on some or the other criterion. The experience of the dialectics of history and the structure of dialectical syllogism emerging from it hints at the fact that history should not be divided into two or four - as Hegel attempted to do - but into three. The metaphor of organism on the other hand, the organism functioning properly only when there is an internal fight within it going on, that is

fact of treating societies in terms of the philosophy of history should be mentioned first. The application of the above conceptualization is confirmed by the use of such concepts as development, progress, periodization etc. As far as periodization is concerned, quite like Cieszkowski, it was also Comte who divided the history of humanity into three periods (cf. Szacki 2011, chapter VIII-IX). 
when it develops and materializes its life functions with procreation coming to the limelight; introduces to the reasoning over history the element of future. What is important here is the fact that Cieszkowski does not only mean the alteration of the typology of what is gone but primarily the strict interconnection between history and the essence of time. Because the essence of time is not located in time itself, Cieszkowski might as well say that history coincides with eternity. History proceeds along the axis of time and its internal divisions are correlated with its three dimensions. The fulfillment of time, which Cieszkowski associates with the future, does not involve the simple state of time arriving at some terminus, or the exhaustion of the future for the sake of the past, after which there would be merely timeless existence. Instead, what it means is for time to reach its essence, folding the past, the present and the future, thickening of time in its essence, concentration and filling time with itself. That moment, in which time becomes what it is, is the future. The knowledge on it is the teleology of history. Being the knowledge of the future, Cieszkowski's historiosophy certainly cannot embrace the information concerning particular events. If we mark the most outstanding part of the author of Ojcze Nasz [Lord's Prayer] philosophy of history as praescentia (as pre-knowledge) or provisional knowledge, then it might be concerned only about the essence (Apriori). The expression of that knowledge is the prayer Ojcze nasz [Lord's Prayer], which demands the appropriate interpretation. There is a similar problem in Plato's thought; yet, unlike in Plato's philosophy, Cieszkowski's pre-knowledge does not refer to the past but to the future. It means that it is not a sort of knowledge that prepares a subject to recognize what is forthcoming; it is neither knowledge of contemplative nature, but it is knowledge which allows for cognition as action. Although from the knowledge of the essence of the future does not follow what will inevitably occur - between the necessity of the essence and the adventitiousness of what is out there is a chasm - it is still the case that this knowledge acquires the certainty through the fact that the future depends on the realization of that knowledge in the action itself. Thus, it is knowledge which reassures itself in the free action. That is why the end of history is at the same time the 
commencing point of it. Only in the Opening Epoch, the Kingdom of Action is possible. "The philosophy of history is opening before us the sealed books of Daniel" (Cieszkowski 1972, 13) - Cieszkowski concludes.

The philosophy of history conducted to its logical ends must relinquish itself and become the "practical philosophy" or "the philosophy of practice" (Cieszkowski 1972, 87). As a social act, it is at the same time "active intuition” being the basis of each kind of mysticism. As was rightly noted by P. Bartula "in the philosophy of action Cieszkowski overcomes the dualism of spiritual and practical activity. The mystical bound with the Absolute is not inconsistent with the practical activities in the Earthly life" (Bartula $2006,37)$. Hence, following the typical typology of world-views presented by Karl Jaspers, Cieszkowski's philosophy of history may be called the mysticism of the demonic type (Jaspers 1919, 394-395). It involves the dialectic conjunction of mysticism which searches for other-worldly God with the total denial in the name of what is earthly. Demonic mysticism quite unlike ecstatic mysticism of Plotinus - is "the mystique in the world of objects", is an action and working for the sake of this world. That is the action in which there is an eternal sense and meaning. According to Jaspers, Kantian mysticism is the one of that sort. Recalling the thought by the philosopher from Konigsberg, we can thereby confirm the remark by Marek Szulakiewicz, who stated that Cieszkowski's philosophizing is in accordance with Heidelbergian tradition "suspended between Kant and Hegel” (Szulakiewicz 2004, 19-20).

That strict relation between the trichotimic division of history with the emphasis laid on the future, in which the time will fulfill itself - certainly dates back to traditional Christian historiosophy, whose paradigmatic example was established by St. Augustine. The supremacy of Cieszkowski's historiosophy over revolutionary ideas entertained by young Hegelians as well as the later prophets of the grim future such as Nietzsche or Spengler, rests of the fact that Cieszkowski is aware that any philosophy of the future is genetically and essentially connected with Judeo-Christian epos.

Those „sealed books” suggest that history might have the character of mystery. Mystery is „a contradiction which has not been solved yet” 
(Cieszkowski 1922, 173). On some other occasion, Cieszkowski resorts to the concept of a riddle. In accordance with Aristotle's observation having it that "the essence of a riddle is that by talking about what is really out there it combines impossibilities", Cieszkowski is attempting to reproduce the authentic character of the reality of history by those means. The antithesis assumes the form of a riddle- quite similar to the one posed once by Sphinx to Oedipus:

Because each antithesis, each substantive contradiction is a kind of a riddle, similar to the ancient Sphinx overpowered by Oedipus. Once the solution to the riddle is grasped, once its word is revealed - then the real riddle de facto solves itself: the said mysterious Sphinx collapses and disappears.

Until now then, the progress of humankind was a similar sort of substantive riddle - a bundle of insuperable contradictions - Sphinx not allowing us to go further because we had not guessed his words. Guessing the words of that riddle simultaneously means the contradictions being impervious to their mutual reconciliation (Cieszkowski 1922, 119).

Finally, for the description of the essence of history, its impenetrability and contradictions, Cieszkowski - also the Neo-Kantians of the Marburg as well as Baden school will express their beliefs in the similar tone - uses the concept of the equation with the variable X. "That $\mathrm{x}[\ldots]$ denotes the moments of the future" (Cieszkowski 1972, 340).

Comparing history with an equation and categorizing history into three epochs, which correspond with three moments of dialectical syllogism, being something like mathematical power (ibidem, 71), reveals the mathematics-like oversimplifications. Is it valid to resort to that sort of reasoning in historiosophy? - Cieszkowski is wondering. The answer seems surprising. On the one hand, it appears that "mathematics cannot develop the whole range of concepts; it is beyond the shadow of a doubt" (ibidem, 71). On the other hand, because the category of quantity - in Cieszkowski's account - precedes the concept of quality (ibidem, 259), "mathematical inductions" are the basis of histiorosophical process. Mathematics "is the basis of everything” (ibidem 71). That „justification of the philosophical 
system by resorting to a mathematical basis" is not a subtle correction of Hegel's system but a serious proposal to be developed in the future.

From it, there will result the recognition of the whole mathematics as not only purely logical but even as the fundamental domain in logic. Furthermore, it will commence the whole system of knowledge not from ontological specifications, which are too substantive at the very beginning, but from numbers and formal relations (ibidem, 259-260).

And then again, it must be noticed that courageous, however unimplemented, mathematical proposal of conceiving of historical reality is not merely some complementation of the fundamental experience of the dialectics of history but it is an attempt at its even stricter formulation. Within the realm of dialectical understanding of history, each category has its own genesis, which proceeds according to thrichotomic typology. However, since the very understanding of history has its genesis, the situations recurs at every level of reflection ultimately giving rise to something which resembles the mathematical structure of self-similarity, which was spectacularly developed in the early geometry of fractals. Obviously Cieszkowski could not follow the consequences of that comparison, but his vision of the worlds within the worlds of historical reality in which "everything is reflected in everything else because one principal thought permeates the essence of everything" (ibidem, 32), almost like a blend of Leibniz's monads - makes this parable more likely.

Another symbol is - this time of geometro-theological nature, to which Cieszkowski willingly refers together with other romanticists, is the picture of the cross. History is laid-out leaning on the idea of the cross; the horizontal crossbar representing the current succession of events. If one considers the history as a whole, it seems to assume the shape of a surface on which the point representing "the current" moves along almost as the light of the scanner. If two consecutive events constitute "eternal continuity" of historical process ("longitudinal section"), then simultaneous events occurring on the plane of history "adjacently to each other" (“cross section") in which particular nations take part, they form a special 
distinctness (Discretion)", "multifarious and independent circles" (ibidem, 25). History is an intersection of the diachronic and synchronic orders. Or, as put by Cieszkowski, an intersection of one time and different places, one place and many times (Cieszkowski 1922, 196). When disentangled, that thought leads to an interesting picture of history as an explosion, as a result of which one obtains an infinite number of worlds - something similar to Pascal's conception of "infinite spaces". According to the fundamental experience of dialectics, history demonstrates the absolute multi-dependence, which in turn determines each of their individual moments by referring to any other moment. Only history as a whole, understood as an Absolute, does not have its external point of reference any longer. It means that any wordings once used to describe the opposition of that (historical) reality and something other which was supposed to transcend the former - as for example, the real and the ideal, here and there, the world and the other-worldly, the immanent and the transcendent, the temporal and the timeless, laity and divinity etc. - they all make sense only within history. There is no one exclusive and neither two worlds,

But there is an animate varying world - the grandiose world, omni-eternal (universe) composed of various limited world, ramifying into layers merging into one another, unfolding and folding different positions which despite their relative fleeting still co-last and fulfill the former world.

That common world - that is Heaven - embracing the multitude and millions of the world - and among those millions one is called Earth (ibidem, 195). ${ }^{8}$

That dialectical transition of some worlds into others; what is here into what is there, the transition of Earth into Heaven etc. is the "immanent dialectics", the transition from the potential to the actual; of what is merely implicite into explicite. That concept by Cieszkowski oscillates about the idea which can be referred to as - following A. Walicki - "terrestrialization of eschatology" - the idea typical of millenarian movements, according to

8 Cf. Cieszkowski 1923a, 239 and the following. The above description of the "economy of the world" revokes a very similar picture of reality found in Nietzsche (cf. Nietzsche 1905, 448-449). Nietzsche calls it Dionysian world. It i also Goethe's worldview that can be subsumed under the same vision (cf. Löwith 2001, 41). 
which the early transcendent eschatology is essentially Earthly eschatology (Walicki 1972, XXXIV-XXXV). ${ }^{9}$ It entails the need for "the restauration of matter" then (Cieszkowski 1972, 86). With reference to its frenetic conception of reality, that dialectical movement was called by Cieszkowski, following French thinkers, "objective eternal recurrence” (Cieszkowski 1922, 196).

From the above, it follows that when Cieszkowski states that "only one thing stands above history and that is Absolute Spirit, God. That is why, while everything else in the world is subject to history, all those other things are subject to God" (Cieszkowski 1972, 48) - that assertion should not be construed in that manner as if the said God were to be an entity transcending historical reality. God was a transcendent entity relative to historical reality. What must be conceded is "the combination of God with the world and adjusting the world to God". It is reducible to "the ascension to Heaven of Earth and the descension of the Kingdom of Heaven onto Earth” , “omni-perfectionism of God” (Cieszkowski 1923a, 262-263). God is the principle of history, history is God crucified, which is the permanent paradox for people's common sense.

From the commonsensical position we might say: There is no contradiction in God, and speculation elevates those contradictions to the very climax and thus it melts them in the greatest Oneness, not resigning from the power of their differential. And that is why the speculation is allowed to say: God is full of contradictions because he is the greatest Oneness and the basis for all possible contradictions (Cieszkowski 1972, 74).

There are also other formulations that correspond to that concept of God as a principle of history unfolding in accordance with the dialectical pattern. These formulations remind us of the already-mentioned principle of self-similarity, according to which each category not only describes what is dialectical but is also subject to the dialectical law of development. It means that history itself has some history within itself. Spirit, emerging

9 On the secular chiliasm of revolutionary thought in XIX century v. Mannheim 1992, 174-179. 
from Nature, ultimately creates the history of mankind, which is in turn something like a highest peak or the top of the world. It can be also said that history is, on the one hand, a microcosm in which the history of the world presents itself in nuce, and on the other hand, it is a macrocosm, sensorium commune of the world; that is because that is in them that the universe reaches its maximum of meaning (ibidem, 33, 48).

As far as the provisional summary of the above-stated Cieszkowski's historiosophy, one can enumerate at least a few attempts at grasping the essence of history on the basis of the fundamental metaphysical experience, which is the said experience of the dialectics of history. Hence, history is the materialization of the dialectical syllogism, the conflict of opposites, organism, a mystery, equation, surface, cross, the synthesis of immanence with transcendence, sensorium commune of the world, microand macrocosm, Absolute and Judgment Day.

\section{The philosophy of history and the contemporary awareness of pluralism}

To what degree can the afore-stated historiosophical vision of Cieszkowski, which is the expression of the epochal experience of the dialectics of history, can be regarded as an inspiration for contemporary thought?

In the face of what XX century brought about, the philosophical agenda by Cieszkowski must have revealed the helplessness quite similar to the one the absolute idealism by Hegel was subject to. As an antithesis to optimistic-reconciliatory message of the author of God and palingenesis, there appeared on the turn of centuries the all-embracing cultural feeling of being blasé and discouraged. Nihilism, prophesied by philosopher and writers of XIX century, disclosed shortly its cruel countenance in the form of two world wars and the division of the world by dint of the iron curtain. It is hard to envisage a stronger antithesis to "the Kingdom of Heaven on Earth" than Auschwitz and Kolyma. Searching for the oneness within a variety (the well-known synthetic both-and) terminated in the first half of the previous century with the attempt to create the civilization of 
the ultimate exclusion (either-or). After that epoch of the total destruction, the whole culture became problematic: not only its most subtle and ephemeral form, that is poetry (Adorno). Let us return to the experience of the dialectics of history laying foundation to the syllogism of the last two centuries: as an antithesis to the above-mentioned vision of Cieszkowski, there appeared the epoch of transition, in which the consistent destruction of any ontological and axiological differences and uniformities was conducted. Wodziński calls it "an epiphany of evil". As much as the awareness of history tried to march across history and transcend it by dint of cancellation (Aufhebung), the transition between it and the epoch of evil, which followed it, occurred as a result of overcoming (Überwindung). The latter stems from the logic of what should be overcome and it is its fulfillment (the end of history). Let us recall that the antithesis of the dialectical syllogism not only occurs as a mere negation of assertive contents but, by negating them it unravels their truth, which in turn it accommodates and thus it contradicts itself in the end thus creating the tension in need of some solution. Following Wodziński, one can say- one it could be possible but for the fact that dialectics of that sort has any meaning only as far as what is rational and historical goes, and hence it becomes a nonsense in the post-historical epoch (Kozłowski 1996, 109) - that after a assertive epoch of axiological and ontological differences, there comes an anti-assertive epoch characterized by the lack of any differences at all (the epiphany of evil). The final moment of that antithesis or a sing of the forthcoming synthesis is the culture of the first decades of the half of XX century. It is conceived of not as an effect of Aufhebung or Überwindung, but as an effect Verwindung - „folding” and „bending” but also „suffering from the loss of" and ,recovery”.

What experience lays foundation to the cultural climate of the second half of XX century? At the first glance, it might seem that is the experience of extreme indifference, fragmentation, dispersion, which slowly but steadily transform into a positive experience of pluralism. The latter sentiment emerges from the landscape of post-war tatters and rags. The historical awareness revealed the variety which it tried to assimilate within Oneness. 
In that way, the variety assumed the form of contradiction; there emerged the state of tension and conflict. In the culture of evil, it was attempted that this tension should be relieved through the "total war" leading to the exclusion of all the differences. Instead of homogenous oneness, there emerged a grim void. In the world of the second half of XX century, particular components of that variety - almost like young grass seeds after the forest conflagration, still in smoke, stink and still threatened with the successive outburst of fire - they slowly started to fill the emptied space. Variety appeared, the variety not seeking for the confrontation, the elements of which co-exist adjacently to one another, apart from one another or without one another. The epoch of leaving the shadow and enjoying our existence, however wounded, limping, lonely and guilty, void of the past and the future that existence might be - who would be ready to willfully reminisce over such past and what things of interest might the future after that epoch might bring? Still, that is the existence after all. The epoch of planetary carpe diem and aesthetic triumph of variety and individualism. The time of reorganization but now not on the basis of organism but on the basis of patchwork art. This time of solstice Vattimo calls (following Heidegger) the process of overcoming (Verwindung) of history specified by metaphysics. Overcoming metaphysics does not mean, as earlier, its transcendence (Überwindung), being carried out under the auspices of some new principle of determining the future but means such a reference to the past that is its re-occurrence (Wiederholung) and "thinking about" (An-denken). That turn to the past does not occur because the past is the whole Truth but because there is no Truth and what is left is the sum of the acts of searching and going astray which befell mankind each time it opens itself to the world (Vattimo 2006, 160-165). That position virtually coincides with the hermeneutic concept of experience, which - as put by Gadamer having followed Hegel - essentially has historical and dialectical nature (Gadamer 1993, 330). Even if in Gadamer's account it is not the same concept of history and dialectics, which occurs in Hegel's account, it has some meaning only when the historical awareness is still holding, hermeneutics being the successor of the said historical awareness. Even if Gadamer's thesis is 
right, it means that our decision as to the way of presenting Cieszkowski's historiosophy, the way involving laying the experience of the dialectics of history in the centre of the system - the turn, which, as it transpires now is the double pleonasm - the thesis departed from the slowly receding but hermeneutic-postmodern attitude (which still affected the contemporary consciousness, and therefore also ours) and it aimed at the clarification of that awareness by revoking those elements of the past which are its present contents. Cieszkowski's account of history (presented above) is closer to hermeneutic concept of experience as described by Gadamer than to Hegel thought because, first, due to the dimension of future being incorporated into history it remains in accord with the key principle (for hermeneutics) of openness and variety; second, as a result of the combination of the future with the action, it does justice to the hermeneutic primacy of what is practical; and third finally, it expressed the experience of history through interpretation (The Lord's Prayer).

Yet, we stated before that hermeneutico-postmodern reasoning is in a sense in retreat these days or at least it lost its provocative vein. Even if one can doubt its real termination, it is certain that nobody is deluded into thinking that as far as the awareness of history goes, we are witnessing its fading away; thus, hermeneutics, which had emerged and evolved from the awareness of history, must be redefined. What comes into the limelight is the belief that we are living today in the epoch of post-postmodernism and post-hermeneutics (whatever it means). What seemed binding still in the eighties and early nineties of XX century, is insufficient on the turn of XX and XXI century after the rise and blistering expansion of virtual reality and all the life transformations attached to it. That new digital realm of communication between people and things, being a "new" manifestation of the reign of the essence of technology, being understood - having followed Heidegger - as Verwindung Ge-stell (literally “framing”) (Heidegger 2002, 22). ${ }^{10}$ That epoch is christened by many authors even as the epoch of real "reconciliation" of the Spirit with itself. If one of the leading ideas of his-

10 Cf. also Vattimo 2006, 160-168. 
torical awareness - Nietzsche must be mentioned in this context - was the belief that history involves transience and "becoming", that history is an interplay and the conflict of different forces. Whereas some of these forces are prevailing, the others disappear, it must be said that with reference to the contemporary post-historic state of affairs, nothing disappears and nothing is transient. Everything got stand and presents itself as being at each time at our disposal.

So, when Gadamer says:

Wilhelm von Humboldt perceived the characteristic fulfillment of the Spirit in the richness of grandiose individual forms the Spirit is characterized by, [and with reference to Herder, the historical worldview posited that] the variety of individual phenomena characterizes not only Greek but any historical life as such and that what the value and the meaning of history involves. [...] and at its basis there is a formal idea of variety. That ideals is truly universal. It cannot be in principle shaken by an experience of history and neither by the astounding proof of miserability of human affairs. What apparently counts against that meaning - the transience of everything what is earthly - amounts to its real foundation. In transience, there is a mystery of inexhaustible productivity of historical world (Gadamer 1993, 203).

Then today's cessation of transience causes not only the uniformization of everything but rather by dint of Verwindung (overcoming and bending) tightening the said historical variety (subject to Verwindung) in the current "now" of virtual reality. "(...)" the simultaneity of what is non-simultaneous, became the new nature" (Welsch 1998, 298). Using Cieszkowski's terminology, longitudinal section of history was folded, bent and incorporated into the cross section. After the "death of God", what remains from the historical cross was only a cross bar - suspended in the air, the forced openness (symbolized by the open arms of crucified Jesus stuck to the wooden cross). The openness is forced because, whether we want it or not, we are destined to it. If the discourse about philosophical history is to make any sense, the history cannot be understood diachronically but synchronically. Thus, the task of contemporarily understood philosophy of history would 
overlap with what, for instance, Welsch describes as the transversal reason. The latter proves to be "quite a characteristic form of postmodern reason" and "all its operations process horizontally and involves transitions" between the types of rationality of different types (ibidem, 406-407). That transition of the reason amounts to its transitory, historical being: "There is no reason, reason is in the state of "becoming" and it is "becoming" not elsewhere but in its own processes. Some people might be annoyed that we are approaching Hegel from different angles" (ibidem, 425, 427). Yet, can't we ask, aren't we closer to Cieszkowski?

At the first glance, this sort of juxtaposition of the philosophy of history with the contemporary awareness of pluralism seems ridiculous. Welsch plainly dismisses the suspicion of the resemblance of traversal reason to Hegelian reason of history, by stating that it must be conceded that both of them is a reason transitioning opposites; yet, these transitions the reason of history realizes with the ultimate goal in mind, which is the totalizing entirety (ibidem, 429-430). Transversal reason resigns from the insight into such an entirety. However, it must be noted that neither does Welsch dismiss the entirety but he presupposes its weaker form. Otherwise, it would be difficult for him to speak about the difference and the variety of rationality, at the same time not assuming full arbitrariness (ibidem, 178). Each transition demands some terra comparationis. That is why Welsch anyway smuggles some idea of entirety even if it is not clearly defined there. It can be corroborated by such phrases as "the immanent correlation and the intersection", "environment, cancelling contradictions, "masterful reconciliation" (ibidem, 408, 422, 407, 440), or finally the statement that "reason despite its various forms amounts to oneness" (ibidem, 405).

Even if the difference between the traversal reason and the understanding of history, as far as their unifying function goes, is not so humongous as it might seem at the first glance, there still appears to be a problem while searching for the similarities between the account by Welsch and Cieszkowski. Namely, it is all about the said connection between history and time mentioned in the thought of the author of God and palingenesis. If the statement that nowadays history is getting concentrated on the pres- 
ent, thus becoming the practice of mediation between particular discrete (Discretion) discourses or rationalities is right - Cieszkowski speaks about "various and independent circles" and the multitude of the worlds - then we rather adhere to the timeless (Hegelian one) concept of history, in the light of which what happens is what had happened and so it is and cannot be otherwise. We mentioned earlier that Cieszkowski transcended this understanding of history which conceptualizes it as narrowed down to the past, resp. the present, complementing it with the dimension of future. Thus, he rigorously connected history with time, bestowing upon history the open-ended character. So, is it justifiable to identify the present with the future and encapsulate the entirety of time within the space of the present? Let's take note of the said concept of Verwindung (overcoming). The fulfillment of time in the future, which Cieszkowski talks about, involves folding and the concentration of time in its essence and thereby the transition from time to eternity. The latter, despite some immobility, is characterized by the internal dynamism, which can be called (following Heidegger - by the cognomen used earlier to characterize the modus of the Spirit's existence), "being-out-of-itself” (Ausser-sich) (Heidegger 2006, 329; idem, 2004, 413-414), and thus a "radical difference". Thus, today's present, in which history got bent and unfolded and thus history became actual. That vision might be compared to Cieszkowski's account of the future, in which time got filled with itself. In that open-ended present/future, reason is searching for the pathways between particular - subjective and objective and absolute ones - forms of the Spirit, which Welsch calls the types of rationality. The transversal reason is a cross-type reason of history, the historical reason is a longitudinal transversal reason. One of the most important problems of contemporary philosophy oriented at the affirmation of pluralism is the issue of the possibility of the co-existence of the variety. The aim is to reach some weak form of harmony. Dialogue, consensus, co-existence, democracy - are the slogans which still drive the discussion of the contemporary theoreticians of culture. That is the issue of dialogic (dialectics), which would enable to reach the consensus between conflicted parties. What sort of logic is the transversal reason governed by 
and what does the "logos of history" involve? The task for transversal reason, which is the faculty of self-reflection (überlegendes Vermögen), Welsch defines relatively to particular types of rationality in the following manner: verifying and explaining the structures and „internal demands for particular rationalities”, ,explaining, articulating and comparing and thanks to these: correcting the errors within particular types of rationality and discovering the gaps in the profile of rationality and [...] allowing for their development" (Welsch 1998, 420). These tasks of the reason, unfortunately, remind us of, contrary to what Welsch professer, the tasks of intellect. Is the difference between reason and intellect to be predicated on the fact that the latter is the faculty of "rigorous comprehension and exercising concepts in one domain” (ibidem, 405)? Isn't the transversal reason really - despite the assurances by Welsch - in comparison with the intellect "the faculty of comprehension at a higher and fuller level" (ibidem, 406)? To avoid the danger of equating reason with the intellect it is not enough to attribute to the former larger competences but its distinct logic must be proven. In Cieszkowski's thought, the transitions between various manifestations of the Spirit is the dialectical process. The logic of history involves the realization of the dialectical syllogism. Certainly, for the representative of the type of reasoning free from schematic generalizations, it is a misunderstanding to attribute such a logic to reason; yet, even among them, one can find such persons who do not evade the concept of dialectics. What is more, in the works of Welsch, just to stick to his case, one can find as many as three forms of it, which positively refer to their own historical roots: Plato's dialectics, Kantian transcendental dialectics and Hegelian dialectics (ibidem, 420, 427, 430). Is it possible to find a common denominator for these concepts despite the differences between them? First, what is readily noticeable is the fact that they both indicate contradiction. Dialectics is a science of observing and resolving contradictions. The latter is not manifested only as any indifferent juxtaposition of contradictory senses but as an obstacle and difficulty in the realization of certain interest. That contradiction has the nature of a problem, riddle or an equation calling for the solution. Therefore, the latter seems to account for the logos of history 
better than the judgment. Cieszkowski conceives of history as a riddle or a mystery. To grasp these concepts, he suggest dividing his historiosophy into three parts, which stem from three distinct questions (how?, what? and why?). To describe history, he uses the concepts referring to living organisms: embryo, tree and an organism. Nowadays, people more willingly use the analogy to a spider web or a rhizome (ibidem, 195), which is aimed, as I believe, at emphasizing the aporetic moment of what is heterogeneous. A question as such is closer to the concept of reason (Sobota 2004, 135-148). On the other hand, the assertion of judgment is primarily a function of the intellect. The basis of historical reason and traversal reason is eroteric reason, which is reason in search. Cieszkowski criticized Hegel for the fact that the latter - instead of searching for reason in history, he has simply found it. It is also Welsch who emphasizes that the links between the types of rationality are not obvious; they are yet to be discovered (Welsch 1998, 422, 426). That active character of reason serves the purpose of protecting the entirety of what is heterogeneous from it being closed: "The entirety must be open-ended" (ibidem, 177). As Gadamer says: "the essence of the question is the opening of possibilities and keeping them in the state of being open" (Gadamer 1993, 284). That question affirms not only the existence of the variety of possible answers. By ordering them in terms of what they ask about, it always reaches beyond what is given, in the search of the true answer, which would not annihilate the question like the solution eliminates the problem - but instead it will provide the question with the wider extension of its validity. The question as such has the intrinsic open-endedness but it is also transgressive.

Historically speaking, the feasibility of eroteric reflection of that sort was first pointed out by Martin Heidegger. He was followed by the representatives of many movements of contemporary philosophy. His wellknown Seinsfrage revokes (rising them from obscurity) the significance of the question as such, which question combined with the traditional problem of metaphysics, that is being, creates the new organization of the philosophical discourse (Sobota 2012-2013). Its task is no longer the analysis, explanation, articulation, comparisons, controlling and correcting 
or etc. but inquiring. Following Heidegger, Gadamer made the "dialectics of question and answer" a logical structure of hermeneutic experience. What is interesting is that Vattimo, whose thought was also derived from Heidegger and his understanding of reasoning and who inclined towards hermeneutics, dismissed the question about the being as the one which "can lead us to mysticism", favouring "the hermeneutic or nihilistic aspect of Heidegger's thought" (Vattimo 2006, 166). The concept of mysticism, which appeared in the form of the objection against Heidegger's account, reminds us of Cieszkowski's mysticism and combines question, reason and intellectual insight into one. It is also Welsch who emphasizes the intuitive character of reason, likening it to intuition (Spürsinn) (Welsch 1998, 426).

Talking about mysticism, it is impossible not to ask about God. It is difficult to find that concept in contemporary philosophical accounts, which associate the concept of Absolute with the cardinal sin or the source of fundamentalism. According to postmodernists, from that sin not only the earlier philosophy of history is suffering but also science and technology as well as post-war counter-cultural movements, inspired by the slogan of new spirituality do so. So, where one principally resigns from oneness and entirety, there the concept of God, which was traditionally semantically associated with these predicates, becomes very problematic indeed. However, it is not impossible. Especially when one takes into account the genesis of the contemporary awareness of pluralism, which is "a heritage of history" (ibidem, 252).

Already in Cieszkowski's thought, we deal with the non-Orthodox attitude to the problem of God, which attitude goes far beyond what is proclaimed by Catholic theology. God is omni-conditionality and the foundation of all the contradictions. The historical consciousness, the roots of which date back to Christian concept of the history of salvation, does not abstain from referring to theological interpretations. It is conspicuous both in the romantic thought of F.D. Schleiermacher, Hegel's philosophy and historical school. In early Schleiermacher, faith is understood as insight and sentiment does not concern personal God but the infinite universe, infinite chaos, "in which each point represents some worlds". Religion is 
"historical cognition" (Schleiermacher 1995, 79). Hegelian philosophy of history takes advantage of the concept of Spirit as an Absolute, which moving through history, becomes a being in itself and for itself. The process of God approaching history results in a sort of equality of any forms of Spirit. In historical school the equality transforms into historical relativism. But even the latter does not entirely resign from the concept of God. As Gadamar says:

The old ideal of infinite intellect was applied to cognize history. (...) The idea of infinite intellect (intellectus infinitus), for which everything is simultaneous (omnia simul) was transformed into the prototype of historical justice. A historian, who regards all the historical epochs and phenomena as equally justified in the face of God, approaches it. (...) in the historical thinking, universe as a design of God is elevated to the rank of being conscious of itself. Obviously, it is not a conceptual consciousness: the ultimate result of historical science is »empathetic understanding and common knowledge of everything (Gadamer 1993, 210).

This concept of justice and of empathetic understanding recurs in postmodern thought. In Jeana-François Lyotard, the concept of justice becomes an universal idea and the necessity of „the sensation of an argument” and "sensitivity" differences among discourses coincides with the idea of humanism. ${ }^{11}$ Thus, it transpires that the idea of God, contrary to what today's self-consciousness opts for, is still in effect - however obscured and unclear it is. It is - among others - Wilhelm Weischedel who convinces us how thinking about God is possible in the era of nihilism. Incidentally, he was the one who, in the face of reality conceived of as what is problematic and deprived of solid ground, suggested understanding God, with reference to early apophantic theology, as a source of any inquiry (Woher der Fraglichkeit):

The cognomen »God« as conceived of by the philosophical theology means then that the extreme problematicity leaves behind the superficial reality and

11 For further extensive notes on the subject, see: Welsch 1996, chapter VIII. 
thus, it proves to be the most real reality - real not in the sense of substantial or personal mode of existence but in the sense of absolute, making everything real powerless, effectiveness, which problematicity is characterized by. »God« is this from which radical problematicity permeates all the being and eventually inquiring as such, which puts in the state of suspense all the conjecturally true reality. It might be said that »God « is the origin of problematicity. Yet, the word »origin« should be understood as a verb: as a state of validity of radical problematicity (Weischedel 1994, 30). ${ }^{12}$

\section{Summary}

The purpose of the afore-mentioned sketch of August Cieszkowski's historiosophy with the contemporary awareness serving as the background was to find the spiritual concord between them. We focused our attention on the concept of history, and strictly speaking, on the experience of the dialectics of history; willing to demonstrate in which manner that key experience of XIX century acquired its counterpoint in the contemporary awareness of pluralism and why that was the thought by Cieszkowski that can help that awareness to reach self-transparentness. Did we manage it? The thesis we arrived at posits that the nowadays apotheosis of plurality is a sort of transposition of historiosophical reasoning and much of what is understood as plurality overlaps with the way of conceptualizing history. Following that comparison, we were trying to signalize the existence of many tangential threads between Cieszkowski's thought and the contemporary hermeneutic and postmodern awareness. Thus, implicite, there appeared the "metaphysical" reading of those movements. Certainly, the differences cannot be overlooked but the concept of inspiration we adopted involve the fact the spiritual communion is full of dialectical references.

What we left unstated is a totally different approach to research, probably, even more interesting than the one we adopted. Namely, instead of addressing the said transformations of the philosophy of history in postmodernism and hermeneutic philosophy, we might have searched for the

12 For the notes on the possibility of religion in the postmodern world see: Religia 1999. 
analogy between Cieszkowski's philosophy of history and the same concept being present from the wider vantage point of contemporary thought. Surely, due to that vantage point being adopted, into the limelight there would come other historiosophical positions than the ones around which our present considerations were concentrated - as for example the obsolete movement related to "New Age Spirituality" and "The Age of Aquarius", or the incendiary suggestion by Francis Fukuyama related to "the end of history" (Fukuyama 1996). Especially the last proposal bears a lot of resemblance to Cieszkowski's thought. The considerations hereby would have at least one common thesis with those ones we suggest venturing as an alternative to the ones hereto. Namely, it is not true - what incidentally seems trivial but is still worth recalling - that there was an ultimate farewell to the philosophy of history. On the contrary. A lot seems to imply that we are bound to witness a true renaissance of reasoning in historiosophical terms, which would be even strictly related to XIX-century idea of the philosophy of history. Would it entail the increasing presence and prestige of Cieszkowski's thought? - the time will tell. One thing is certain. The future is still to be discovered.

\section{Bibliography}

Bartula, P. 2006. Jako w niebie tak i na ziemi. August Cieszkowski redivivus. Kraków. Cieszkowski, A. 1972. Prolegomena do historiozofii. Bóg i palingeneza oraz mniejsze pisma filozoficzne z lat 1838-1842, ed. J. Garewicz i A. Walicki. Warszawa: PWN. -. 1908. Prolegomena do historyozofii, translated by A. Cieszkowski (son). Poznań.

-. 1922. Ojcze Nasz, Vol. 1, Poznań.

-. 1923a. Ojcze Nasz, Vol. 2, Poznań

-. 1923b. Ojcze Nasz, Vol. 3, Poznań.

Fukuyama, F. 1996. Koniec historii, translated by T. Bieroń, M. Wichrowski.Warszawa: Zysk i S-ka.

Gadamer, H.-G. 2006. Pomiędzy fenomenologiq i dialektyką - próba samokrytyki, translated by A. Przyłębski, in Przyłębski, Andrzej. Gadamer. Warszawa: WP.

-. 1993. Prawda i metoda. Zarys hermeneutyki filozoficznej, translated by B. Baran. Kraków: Inter esse. 
Hegel, G.W.F. 1969. Zasady filozofii prawa, translated by A. Landman. Warszawa: PWN. Heidegger, M. 2002. Odczyty i rozprawy, translated by J. Mizera. Kraków: Wyd. Baran i Suszczyński.

-. 1996. Przyczynki do filozofii (Z wydarzania), translated by J. Mizera, B. Baran. Kraków: Wydawnictwo Baran i Suszczyński.

-. 2006. Sein und Zeit. Tübingen: Max Niemeyer Verlag, 2006. Polish edition: 2004. Bycie i czas, translated by B. Baran. Warszawa: PWN.

Jakubowski, M.N. 1989. Czyn, przyszłość, naród. Poglądy filozoficzne Augusta Cieszkowskiego. Warszawa-Poznań: PWN.

Jaspers, K. 1919. Psychologie der Weltanschauungen. Berlin: Springer.

Kozłowski, M. 1996. Czy dialektyka zachowuje swa poznawcza ważność także poza filozofią? Kilka uwag o wkładzie Cieszkowskiego w poprawianie Heglowskiej filozofii dziejów, „Archiwum historii filozofii i myśli społecznej” 41.

Löwith, K. 2001. Od Hegla do Nietzschego. Rewolucyjny przełom w myśli XIX wieku, translated by S. Gromadzki. Warszawa: KR.

-. 2002. Historia powszechna i dzieje zabawienia. Teologiczne przesłanki filozofii dziejów, translated by J. Marzęcki. Kęty: Wydawnictwo Antyk.

Mannheim, K. 1992. Ideologia i utopia, translated by J. Miziński. Lublin: Wydawnictwo Test.

Nietzsche, F. 1905. Wola mocy. Próba przemiany wszystkich wartości (Studya i fragmenty), translated by S. Frycz and K. Drzewiecki. Warszawa: Nakład J. Mortkowicza. -. 1906. Z genealogii moralności. Pismo polemiczne, translated by L. Staff. Warszawa: Nakład J. Mortkowicza, 1905-1906.

Pot, J.H.J. van. 1999. Sinndeutung und Periodisierung der Geschichte: eine systematische Übersicht der Theorien und Auffassungen. Boston, Köln, Brill.

Ratzinger, J. 1998. The Holy Spirit as Communio: Concerning the Relationship on Pneumatology and Spirituality in Augustine, Communio. International Catholic Review, 25: 324-337.

Religia. Seminarium na Capri prowadzone przez Jacquesa Derridę i Gianniego Vattimo, 1999. translated by M. Kowalska, E. Łukaszyk, P. Mrówczyński, R. Reszke, J. Wojcieszak. Warszawa: KR.

Schleiermacher, F. 1995. Mowy o religii do wykształconych spośród tych, którzy nia gardza, translated by J. Prokopiuk. Kraków: Znak.

Schnädelbach, H. 1992. Filozofia w Niemczech 1831-1933, translated by K. Krzemieniowa. Warszawa: PWN.

Sobota, D.R. 2004. Krytyka czystego pytania. Rzecz o Kantowskim pytaniu transcendentalnym, in Immanuel Kant i świat współczesny. W 200. Rocznicę śmierci Immanuela Kanta, ed. K. Śnieżyński. Poznań: Wyd. UAM, 135-148. 
-. 2010. Periodyzacja filozofii Martina Heideggera, „Ruch Filozoficzny” LXVII: 731-764.

-. 2012-2013. Źródła i inspiracje Heideggerowskiego pytania o bycie. Bydgoszcz: Fundacja Kultura Yakiza.

Szacki, J. 2011. Historia myśli socjologicznej. Warszawa: PWN.

Szulakiewicz, M. 2004. Heidelberg, Wierzenica i myśl Augusta Cieszkowskiego, in: Spacer aleją filozofów. August Cieszkowski i jego intelektualna spuścizna, ed. J. Banaszak, W. Trzeciakowski. Bydgoszcz: Wyd. Akademii Bydgoskiej.

Vattimo, G. 2006. Koniec nowoczesności, translated by M. Surma-Gawłowska. Kraków: Universitas.

Walicki, A. 1972. Pisma filozoficzne Cieszkowskiego z lat 1838-1842 w kontekstach intelektualnych epoki, in A. Cieszkowski, Prolegomena do historiozofii. Bóg i palingeneza oraz mniejsze pisma filozoficzne z lat 1838-1842, ed. J. Garewicz i A. Walicki. Warszawa: PWN.

-. 2005. Czy jestem „dysydentem”?, Zdanie, issue no. 1-2.

Weischedel, W. 1994. Teologia filozoficzna w cieniu nihilizmu, translated by G. Sowiński, „Znak” 6 (469).

Welsch, W. 1998. Nasza postmodernistyczna moderna, translated by R. Kubicki, A. Zeidler-Janiszewska. Warszawa: Oficyna Naukowa.

Wodziński, C. 1994. Heidegger i problem zła. Warszawa: PIW. 
